\title{
The Implementation of Mathematical Problem-Based Learning Model as an Effort to Understand the High School Students' Mathematical Thinking Ability
}

\author{
Sriyanti Mustafa ${ }^{1}$, Vernita $\operatorname{Sari}^{1} \&$ Baharullah $^{1}$ \\ ${ }^{1}$ Mathematics Education, Universitas Muhammadiyah Parepare, South Sulawesi, Indonesia \\ Correspondence: Sriyanti Mustafa, Mathematics Education, Universitas Muhammadiyah Parepare, South \\ Sulawesi, Indonesia. Tel: 812-4150-0493. E-mail: sriyanti_mustafa@yahoo.co.id
}

Received: September 23, 2018

doi:10.5539/ies.v12n2p117
Accepted: October 30, $2018 \quad$ Online Published: January 30, 2019

URL: https://doi.org/10.5539/ies.v12n2p117

\begin{abstract}
The ability to think mathematically includes many mental activities which involve the workings of the brain. To describe students' mathematical thinking ability, one of the efforts that can be done is to apply the mathematical problem-based learning model. It involves students to solve a problem through scientific method stages, so that students can learn the knowledge related to the problem and also have the ability to solve the problem. This study aims to describe students' mathematical thinking ability through Mathematical Problem-Based Learning Model.This type of research is qualitative. The subjects of the study were senior high school students in the city of Parepare. The data collections were conducted by observing the learning process in class and giving the assignment/test to the students. The collected data were then analyzed qualitatively. Based on the results of research and discussion it is concluded that the students ability to think have sequences in the activities of mathematical thinking with the application of mathematical problems-based learning model. Therefore, the students' mathematical thinking ability is described as follows: (1) identification stage of the problem, (2) the grouping stages, and (3) drawing conclusions.
\end{abstract}

Keywords: mathematical, thingking ability, mathematical problem, learning model

\section{Introduction}

Research on Problem Based Learning (PBL) has been carried out by many people, for example Setyorini et al. (2011) research revealed that concluded that Problem Based Learning (PBL) model can increase the students' critical thinking in learning ununiformly accelerated motion. The other, Duch et al. (2001) stated that this model has the ability to improve critical thinking skills and be able to analyze and solve problems related to the real world.

In the learning process, thinking activity involves the whole person, feeling and will of the students (Mustafa et al., 2017). Thinking includes many mental activities that involve the workings of the brain. According to Alvonco (2012) thinking is the process of the brain processing and translating information (stimulus) that goes through the senses to the conscious or subconscious part of the brain that generates meaning and a number of concepts.

Various theories reveal the notion of thinking, Solso (2008) argues that "thinking is a process of the brain that accesses previous representations to understand or create a new model if it does not exist yet". Thinking is a new process of mental representation through the transformation of information with interactions that involve mental attributes, such as abstraction, imagination, and problem solving. Thinking includes many mental activities involving the workings of the brain (Mustafa, 2015).

Furthermore, mathematical thinking can be viewed as a way of understanding mathematical problems by compiling various sources of study of mathematical objects. Mason, Burton \& Stacey (2010) reinforces with their expression that mathematical thinking is a process and is a very complex activity, so to understand it can be done by giving an example. The process of mathematical thinking describes sequences in thinking activities, for example if in a student arises a problem to be solved, a schematic/chart is still unclear. In addition, the scheme/chart is solved or correlated, and compared carefully to a conclusion (Mustafa, 2015).

The students' mathematical thinking ability when doing mathematical problems in this research adapted the 
process that was revealed by Mustafa (2016) as follows:

1) Identify problems, carried out through activities of making perceptions, analyzing and establishing identity. Perception is defined as the act of composing, recognizing, and interpreting sensory information in order to provide a picture and understanding of the object. This is in line with the phrase Solso (2008) that perception refers to the interpretation of things seen, heard, perceived, or experienced more than just sensory stimulation. Furthermore, sensory events are processed/analyzed according to the knowledge the student has about the object he observes, then determines the identity of the object.

2) Categorize the problem, is the ability to connect objects based on the characteristics of equations or differences. Categorizing problems is done through activities of making perceptions, analyzing and defining groups.

3) Summing up the problem, the idea reached at the end of the process. Summing up the problem is done through linking schemes, analyzing and summarizing. The scheme in question is a category of knowledge that helps students in interpreting and understanding the object being observed. According to Marshall (2005) the formation of schemes involves selective attention and processing, and the attribution is processed simultaneously and sequentially.

To understand the students' mathematical thinking ability, the one of the efforts that can be done is by applying the learning model that accommodates students' ability in solving math problems. Problem-based learning model is a learning model that presents contextual problems, thus stimulating students to learn (Pierce, et al, 1996). In a class that implements problem based learning, students work in teams to solve real world problems.

Problem-Based Learning is one of the innovative learning models that can provide an active learning condition. According to Arends (2001) as cited in Trianto (2009) problem-based learning is a learning approach in which students work on authentic issues with the intent to develop their own knowledge, inquiry and thinking skills, independence, and confidence.

Problem-Based Learning is one of the innovative learning models that can provide active learning conditions to learners. Involving students to solve a problem through the stages of the scientific method so that students can learn knowledge related to the problem and have the skills to solve the problem (Ward \& Lee, 2002; Stepien et al., 1993).

The syntax of learning model based on mathematical problem in this research is adapted from syntax of problem based learning model (Mustafa et al., 2017). The following table shows the syntax of the mathematical problem-based learning model.

Table 1. Syntax of mathematical problem-based learning model

\begin{tabular}{l}
\hline Stage \\
$\begin{array}{c}\text { Stage 1: } \\
\text { Students orientation towards the } \\
\text { problem } \\
\text { Stage 2: }\end{array}$ \\
$\begin{array}{c}\text { Explanation of learning objectives required logistical explanations, phenomena or demonstrations or } \\
\text { stories to raise issues, motivate students to engage in problem solving. }\end{array}$ \\
$\begin{array}{c}\text { Organizing students to learn } \\
\text { Stage 3: }\end{array}$ \\
$\begin{array}{c}\text { Guiding individual and group and organize learning tasks related to the problem. } \\
\text { investigations. } \\
\text { Stage 4: }\end{array}$ \\
$\begin{array}{c}\text { Develop and present the work. } \\
\text { Stage 5: }\end{array}$ \\
$\begin{array}{l}\text { Analyze and evaluate the } \\
\text { problem-solving process. }\end{array}$
\end{tabular}

According to Pierce and Jones (1996) in the implementation of learning models there are processes that must be raised, such as: engagement, inquiry and investigation, performance, debriefing. The process is described as follows:

1) Involvement aims to prepare students to act as a self-directed problem solver that can work with others, confronting students in situations that are capable of being able to find problems, researching and solving 
them.

2) Inquiry and investigation which involves exploring various ways of explaining and implications, as well as activities of collecting and distributing information. Performance aims to present the findings obtained.

3) Frequently asked questions and discussions, are testing the accuracy of the solution and reflecting on the problem solving, for example mathematical problems.

In this research, the problem formulation is how is the Implementation of mathematical problem-based learning models that can improve students' mathematical thinking ability?. This research aims to describe students' mathematical thinking ability; one of the efforts that can be done is to apply the mathematical problem-based learning model, and useful for the development of learning in the world of education.

\section{Research Method}

This research uses qualitative approach. The subjects of the research are high school students in Parepare, who observed as many as thirty-six people. Data collections wereconducted by observing the learning process in class (teacher and student activities), and provide test sheets. Data analysis techniques used are qualitative data analysis techniques. The collected data were then analyzed explorative, which is to explore widely all activities during the learning process including the analysis of the subject's work. The qualitative strategy used was descriptive. The main instrument in this study were the researchers themselves, because the researchers themselves who collect data through the observation (Creswell, 2012) To strengthen the research data used supporting instruments, namely paper test (student worksheet).

\section{Research Findings and Discussions}

The results of the research that will be presented below are strengthened by U. Adiga and S. Adiga (2015), and Duck et al. (2011). In This research, the observation of the activity during the application of mathematical problem-based learning modelin class is described as follows:

\section{a. Orientation Phase}

The activities undertaken in this phase are the students' orientation to the mathematical problems that will be discussed. Orientation activities aimed at preparation include explanation of learning objectives, explanation of required learning tools (including tasks to be assigned to students), submission of phenomena or demonstrations or stories to raise issues, and motivate students to engage in solving mathematical problems selected.

Illustration:

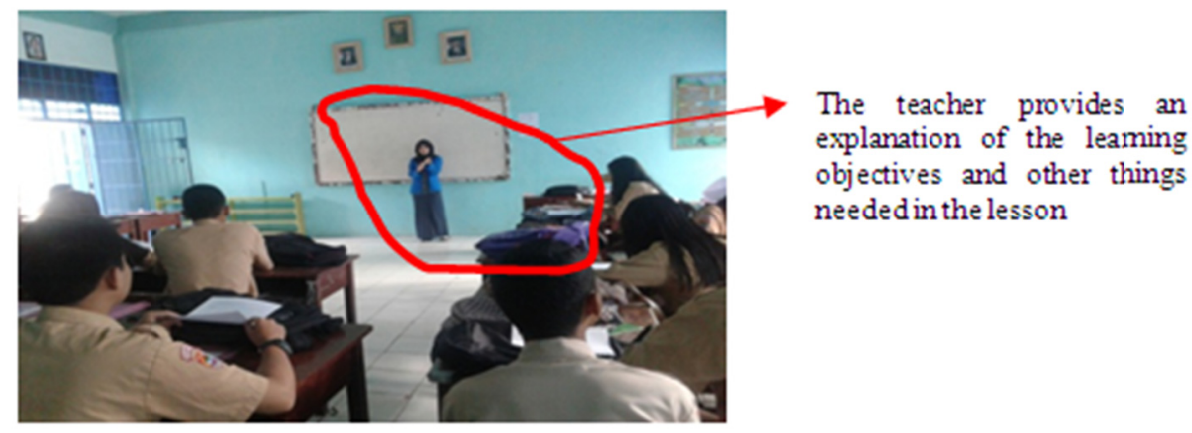

Figure 1. Illustration of orientation phase

\section{b. Organizing Phase}

In this phase, the teacher defines and organizes the students' learning tasks related to the math problems that will be discussed. 
Illustration:

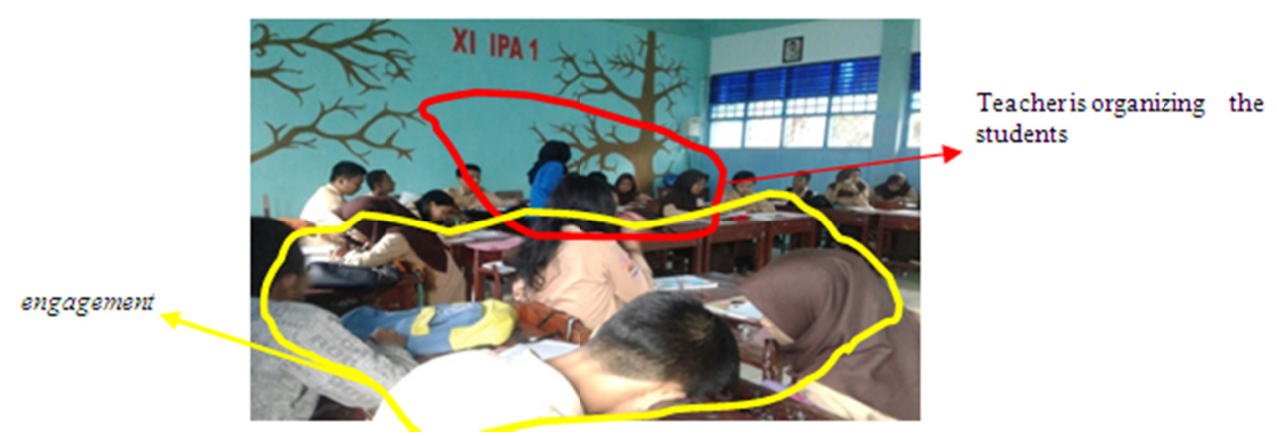

Figure 2. Illustration of organizing phase

\section{c. Mentoring Phase}

In this phase, the teacher mentoring the investigation of the tasks that students do individually or in groups.

Illustration:

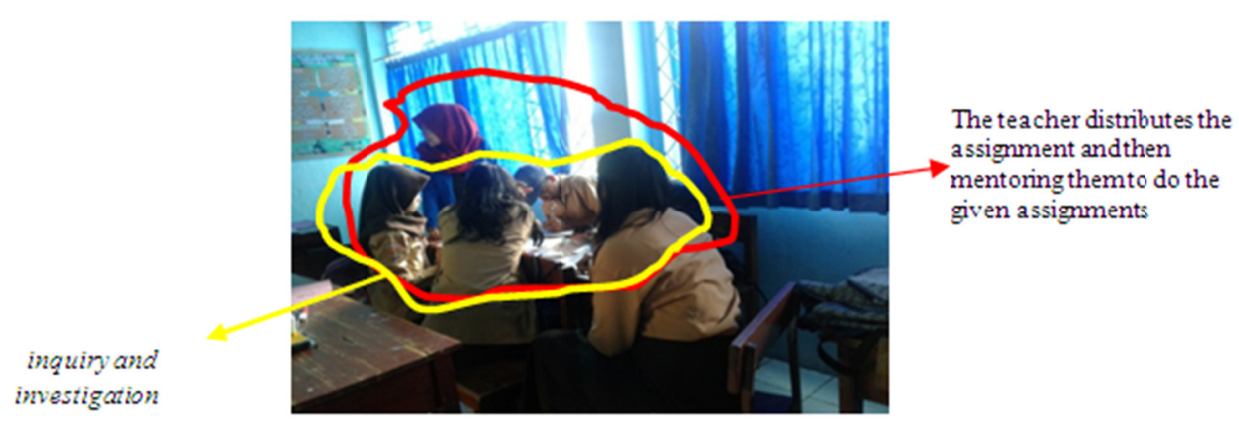

Figure 3. Ilustration of Mentoring Phase

\section{d. Developing Phase}

In this phase, teacher develops and presents the students' work.

Illustration:

Debriefing and discussion

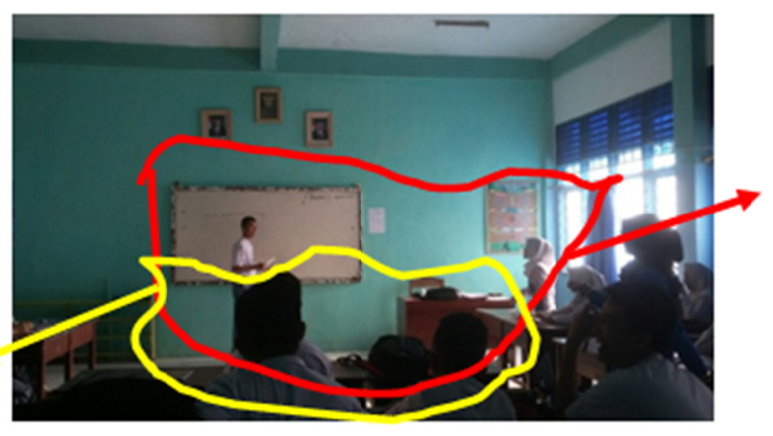

Proper planning and preparation of works such as reports, videos, and teachers help students to share the tasks with their friends.

Figure 4. Illustration of developing phase (performance)

\section{e. Analysis Phase}

In this phase, the teacher analyzes and evaluates the student problem-solving process. Analysis of students' mathematical thinking abilities is explored from the tasks assigned. The following describes students' mathematical thinking abilities after applied the mathematical problem-based learning model.

There are two angles, $\mathrm{A}$ and $\mathrm{B}$ with their respective angular values are $\sin A=\frac{4}{5} \operatorname{and} \sin B=\frac{12}{13}$. The $\mathrm{A}$ is an obtuse 
angle and $\mathrm{B}$ is the acute angle. Please determine:

1) $\sin (A+B)$

2) $\sin (A-B)$

Answer (Subject A):

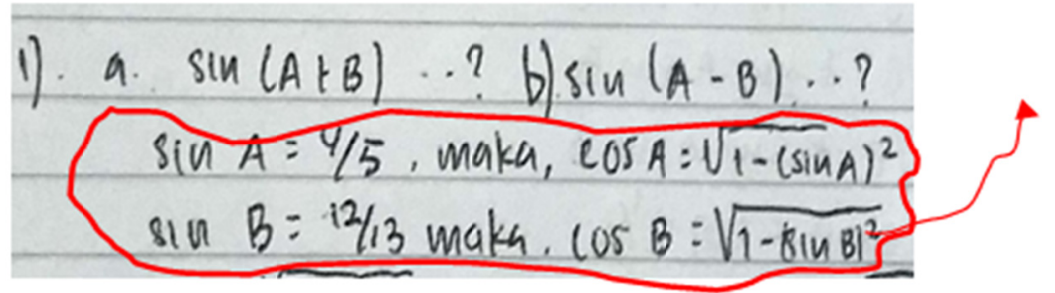

Problemidentification is done by parsing the known elements of the problem and the elements being asked or the problem to be solved.

Figure 5. Problem identification

The process of identifying the problem of the subject begins by making the perception, which is doing the act of recognizing the problem by arranging/interpreting the known elements. This step leads the students to group the next trigonometric problem as shown in the following Figure 6.
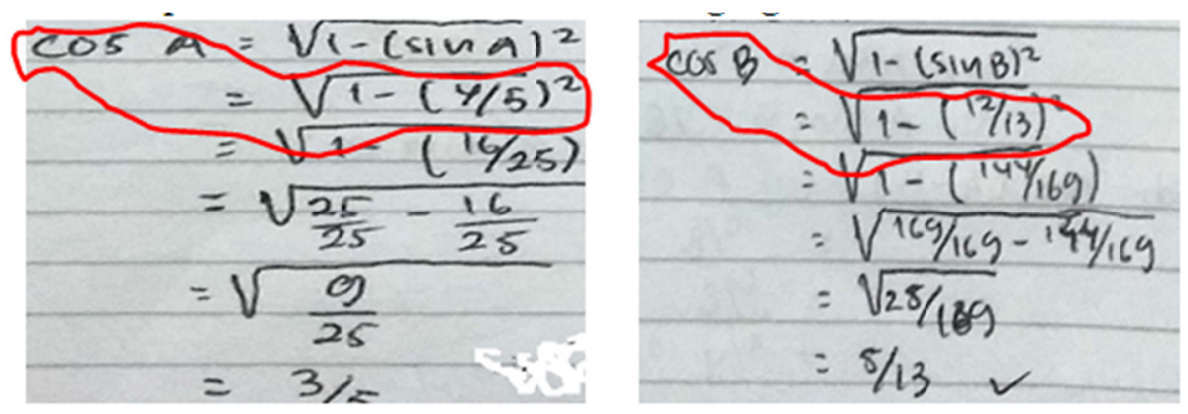

Figure 6. Grouping the problems

The process of grouping the problem by substituting the value of $\sin A=\frac{4}{5} \operatorname{and} \sin B=\frac{12}{13}$ in each of the shapes identified in Figure 7. Furthermore the results obtained from the grouping process are used to determine the final value as asked in the question.

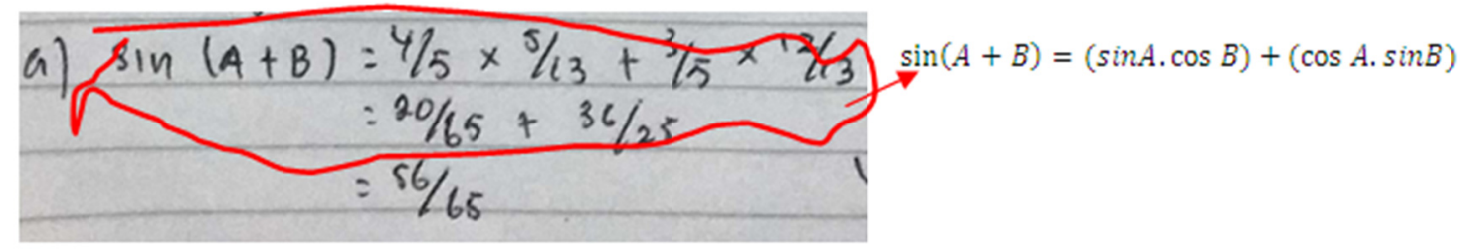

Figure 7. Conclusion

The student's conclusions about the trigonometric problem are directed to the actual use of the formula, so that the value obtained from the process of grouping the problem can be directly substituted. The problem-solving process performed by the students indicates the ability of mathematical thinking that explicitly shows the ability of students to make abstractions to mathematical problems (Mustafa et al., 2017). Tall (2002) reveals that if a student develops his ability to consciously create abstractions from mathematical situations, then the student has reached 
the advanced level of mathematical thinking. The achievement of the ability to make this abstraction is the most important goal of mathematics education. Abstraction is the main construction process in building mental structure from mathematical structure (Tall, 2002).

Mathematical problem-based learning model is directed to sustain the achievement of optimal target or learning objectives that have been set. Learning objectives are divided into the main objectives that are immediate or urgent to achieve (instructional effect) and the purpose of followers or accompaniments that are goals that cannot be achieved immediately or the results are not immediately be picked after the learning took place, but expected in a relatively long time.

Based on research results, mathematical problem based learning model has several advantages as follows:

1) Mathematical problem solving is a pretty good technique for understanding students' mathematical thinking ability

2) Mathematical problem solving can challenge the students' mathematical thinking ability to provide satisfaction infinding new knowledge for learners.

3) Mathematical problem solving can improve learners' learning activities, so mathematics learning can be fun.

4) Mathematical problem solving can help students transfer knowledge to understand real-life problems.

5) Mathematical problem solving can help students develop new and responsible knowledge in the learning they are undertaking.

6) Through problem solving students can learn other subjects (mathematics, science, history, etc.), as way of thinking, and something that must be understood by learners, not just learning from teachers or from books only.

7) Mathematical problem solving can also develop students' ability to think critically and develop students' ability to adapt to new knowledge

8) Mathematical problem solving can provide opportunities for students by applying the knowledge that students have in the real world.

9) Mathematical problem solving can develop students' interest to continually learn even when learning in formal education has ended.

Next, the weaknesses found in this learning model as follows:

1) If the student has no interest or no belief that the problem learned is difficult to solve, then the student will find it difficult to try.

2) Need longer time for the preparation.

3) Without understanding why students are trying to solve the problem being studied, then students will not learn what they want to learn.

The mathematical thinking ability that students demonstrate is in line with what being expressed by Mustafa (2016). In identifying the problem, the students firstly determine the known elements, giving mathematical terms or symbols, then designing the solution. At the grouping stage, students place some terms and make presentation in a simple form, such as drawing illustrations so as to better guide students towards problem solving. At this stage, students can construct the image by bringing the problem into everyday life. The final stage of problem solving by students is to make a conclusion. Conclusion is the final idea that students get based on the problem solving steps that have been done.

The students' mathematical thinking ability is explored according to the result of the work given after all activities in the mathematical problem-based learning model is applied.

\section{Conclusion}

Based on the research findings and discussions abovewhich is based on observations of thirty-six students, it is concluded that the mathematical problem-based learning model can help to understand the high school students' mathematical thinking ability. Each phase of the learning model has an impact on students' ability to uncover students' ideas towards mathematical problems, so they can illustrate the thinking process of the students. Phase consists of Orientation Phase, Organizing Phase, Mentoring Phase, Developing Phase, and Analysis Phase. Therefore, the students' mathematical thinking ability is described as follows: (1) identification stage of the problem, done by uncovering the known elements, the element in question, giving the term and using the mathematical symbol, and designing the settlement, (2) the grouping stages, by placing identified terms/symbols 
and solving problems according to plan, and (3) drawing conclusions, done by linking math problems in everyday life.

\section{References}

Adiga, U., \& Adiga, S. (2015). Problem Based Learning. International Journal of Current Research, 7(6), 17181-17187. Retrieved from http://www.journalcra.com/sites/default/files/issue-pdf/9244.pdf

Alvonco, J. (2012). Meaning of Thinking. Retrieved from http://johnson-alvonco.blogspot.com/

Creswell, J. W. (2012). Research Desain Kualitatif,Kuantitatif approach, and Mixed. Yogyakarta: Pustaka Belajar.

Duch, B. J., Groh, S. E., \& Allen, D. E. (2001). The Power of Problem Based Learning. Sterling. Virginia: Stylus Publishing, LLC.

Marshall, S. P. (2005). Schemas in Problem Solving. Australia: Cambridge University Press.

Mason, J., Burton, L., \& Stacey, K. (2010). Thinking Mathematically. Inggris: Pearson Education Limited.

Mustafa, S. (2015). Proses Berpikir Matematisdalam Representational Gesture Anak Berkebutuhan Khusus (Studi Kasuspada Siswa Autis) (Unpublished doctoral dissertation). Universitas Negeri Malang (UM), Malang.

Mustafa, S., \& Nusantara, T. (2016). Mathematical Thinking Process of Autistic Students in Terms of

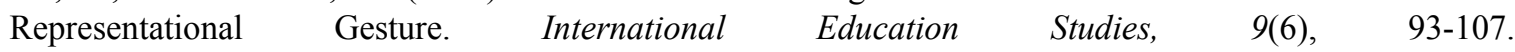
https://doi.org/10.5539/ies.v9n6p93

Mustafa, S., \& Sari, V. (2017). Description of Students' Mathematical Thinking Ability Using Worksheets. Retrieved from https://publikasiilmiah.ums.ac.id/handle/11617/8841.

Mustafa, S., Sari, V., \& Baharullah. (2017). Mathematical Problem-Based Learning Models (with worksheets). Parepare: UMPAR Press.

Pierce, J. W., \& Jones, B. F. (1996). Problem based learning: Learning and teaching in the context of problems. DeKalb, IL: Northern Illinois University Press.

Setyorini, S. E., Sukiswo, B., \& Subali. (2011). Application of Problem Based Learning Model to Improve Critical Thinking Ability of Middle School Students. Jurnal Pendidikan Fisika Indonesia, 7(1), 52-56. Retrieved from https://doi.org/10.15294/jpfi.v7i1.1070

Solso, R. L. (2008). Cognitive Psychology. Jakarta: Erlangga.

Stepien, W. J., Workman, D., \& Gallagher, S. A. (1993). Problem-Based Learning: As Authentic As It Gets. Educational Leadership, 50(7), 25-28. Retrieved from http://www.ascd.org/publications/educational_ leadership/apr93/vol50/num07/Problem-Based_Learning@_As_Authentic_As_It_Gets.aspx.

Tall, D. (2002). Advanced Mathematical Thinking. New York: Kluwer Academic Publishers. https://doi.org/10.1007/0-306-47203-1_1

Trianto. (2009). Innovative-Progressive Learning. Surabaya: Prenada Media Group.

Ward, J. D., \& Lee, C. L. (2002). A Review of Problem-based Learning. Journal of Family and Consumer Sciences Education, 20(1), 16-26. Retrieved from http://www.natefacs.org/Pages/v20no1/v20no1Ward.pdf

\section{Copyrights}

Copyright for this article is retained by the author(s), with first publication rights granted to the journal.

This is an open-access article distributed under the terms and conditions of the Creative Commons Attribution license (http://creativecommons.org/licenses/by/4.0/). 